\title{
A grid-based map for the Biogeographical Regions of Europe
}

\author{
Marco Cervellini ${ }^{\ddagger}$, Piero Zannini ${ }^{\ddagger}$, Michele Di Musciano§, Simone Fattorini§, Borja Jiménez-Alfarol, \\ Duccio Rocchini ${ }^{\ddagger, \pi}$, Richard Field ${ }^{\#}$, Ole R. Vetaas ${ }^{\natural}$, Severin D.H. Irl", Carl Beierkuhnlein", Samuel \\ Hoffmann", Jan-Christopher Fischer", , Laura Casella”, Pierangela Angelini”, Piero Genovesi ", Juri \\ Nascimbene ${ }^{\ddagger}$, Alessandro Chiarucci ${ }^{\ddagger}$ \\ ‡ Department of Biological, Geological and Environmental Sciences (BiGeA), University of Bologna, Bologna, Italy \\ $\S$ Department of Life, Health \& Environmental Science, University of L'Aquila, Coppito, L'Aquila, Italy \\ | Research Unit of Biodiversity (CSIC/UO/PA), Univ. of Oviedo, Mieres, Principado de Asturias, Spain \\ II Czech University of Life Sciences Prague, Faculty of Environmental Sciences, Department of Applied Geoinformatics and \\ Spatial Planning, Praha, Czech Republic \\ \# University of Nottingham, Nottingham, United Kingdom \\ a Department of Geography, University of Bergen, Bergen, Norway \\ " Biogeography and Biodiversity Lab, Institute of Physical Geography, Goethe-University, Frankfurt, Germany \\ " Biogeography Department, University of Bayreuth, Bayreuth, Germany \\ ^School of Earth Sciences, University of Bristol, Bristol, United Kingdom \\ $\checkmark$ Institute for Environmental Protection and Research, Rome, Italy
}

Corresponding author: Marco Cervellini (marcocervellini@gmail.com)

Academic editor: Vincent Smith

Received: 28 Apr 2020 | Accepted: 17 Jun 2020 | Published: 30 Jun 2020

Citation: Cervellini M, Zannini P, Di Musciano M, Fattorini S, Jiménez-Alfaro B, Rocchini D, Field R, R. Vetaas O, Irl SD.H, Beierkuhnlein C, Hoffmann S, Fischer J-C, Casella L, Angelini P, Genovesi P, Nascimbene J, Chiarucci A (2020) A grid-based map for the Biogeographical Regions of Europe. Biodiversity Data Journal 8: e53720. https://doi.org/10.3897/BDJ.8.e53720

\section{Abstract}

\section{Background}

Biogeographical units are widely adopted in ecological research and nature conservation management, even though biogeographical regionalisation is still under scientific debate. The European Environment Agency provided an official map of the European Biogeographical Regions (EBRs), which contains the official boundaries used in the Habitats and Birds Directives. However, these boundaries bisect cells in the official EU 10 $\mathrm{km} \times 10 \mathrm{~km}$ grid used for many purposes, including reporting species and habitat data, 
meaning that 6881 cells overlap two or more regions. Therefore, superimposing the EBRs vector map over the grid creates ambiguities in associating some cells with European Biogeographical Regions.

\section{New information}

To provide an operational tool to unambiguously define the boundaries of the eleven European Biogeographical Regions, we provide a specifically developed raster map of Grid-Based European Biogeographical Regions (GB-EBRs). In this new map, the borders of the EBRs are reshaped to coherently match the standard European $10 \mathrm{~km} \times 10 \mathrm{~km}$ grid imposed for reporting tasks by Article 17 of the Habitats Directive and used for many other datasets. We assign each cell to the EBR with the largest area within the cell.

\section{Keywords}

biogeography, biogeographical boundaries, biodiversity monitoring, habitat, redefining, regionalisation.

\section{Introduction}

\section{Statement of the problem}

The study of the distributional patterns of biological diversity has long been a cornerstone in biogeography. These patterns are observed at many scales, from genes to ecosystems and are driven by ecological conditions, historical processes, geographic constraints and/or evolutionary processes (Lomolino et al. 2005). Dividing the geographical space into relatively-homogeneous units is one of the most traditional approaches in biogeography (Fattorini 2016). Unlike biomes, which are based on similar physiognomic vegetation structure across continents (Mucina 2019), biogeographical regions are recognised on the basis of distinct biotas, especially in terms of endemic and/or spatially clearly limited taxa and communities (e.g. Rueda et al. 2010,Morrone 2015, Fattorini 2017).

Biogeographical regions are an example of broad-scale biogeographical units; the hierarchical system in which biogeography categorises geographical areas, based on their biotas, is defined as 'biogeographical regionalization' (Morrone 2018). However, detecting boundaries between different biogeographical realms, regions or units is not straightforward and some recent tests using biodiversity data question the validity of traditionally-established regionalisations (Bailey 2005, Kreft and Jetz 2010, Holt et al. 2013a, Ficetola et al. 2017, Morrone 2018, Chiarucci et al. 2019). Furthermore, nature typically lacks clear discontinuities and transition zones can be recognised between adjacent biogeographical units (Walter and Breckle 2002,Holt et al. 2013b, Kreft and Jetz 2013, Ferro and Morrone 2014). 
Despite such concerns, 'biogeographical regionalisation' is needed in order to provide reference areas for large-scale ecological analyses, as well as conservation and management practices. A prominent example is the classification of European Biogeographical Regions (EBRs), which has been adopted as an official tool for the EU Habitats Directive (92/43/EEC 1992) and Birds Directive (79/409/EEC 1979). A map of the EBRs is available on the website of the European Environment Agency (EEA 2019). This contains the official delineations used in the Habitats Directive and its extension through the EMERALD Network under the Convention on the Conservation of European Wildlife and Natural Habitats (Bern Convention).

The EBRs were delineated largely based on a map of European vegetation (Noirfalse 1987). The geographic units of that map were reclassified and vegetation types allocated to an initial set of six EBRs (Evans 2005, Evans 2012). As new Member States joined the EU, five new EBRs were then successively added. Unfortunately, a digital map of natural European vegetation did not exist when the EBRs map was created and the paper edition of The Map of 'Natural Vegetation of Europe' was adopted (Bohn 1993, Bohn et al. 2000). Boundaries of mapping units were digitised by hand, resulting in cartographic errors (Roekaerts 2002, ETC/BD 2006). Several improved versions of the EBRs map were later produced, discussed and approved by the national experts of the Member States, resulting in the current version of the "Indicative Map of the Biogeographical Regions" adopted by the Habitats Committee in its meeting of April 2005 (ETC/BD 2006).

Although the EBRs map is now a fundamental tool for biodiversity conservation planning in Europe and is widely used by biogeographers, ecologists and conservation biologists (e.g. see Chytrý et al. 2009, Ibáñez et al. 2013, Templ et al. 2017, Ordynets et al. 2018, Chiarucci et al. 2019, Hoffmann et al. 2019), it is important to recognise that other systems have been introduced. Examples include the phytogeographical map proposed by Walter (1954) and adapted to the fauna by Freitag (1962) and the subdivision proposed by Illies (1967), Illies (1978) for the limnofauna, which remains the standard reference for studies dealing with European freshwater animals. Amongst the most recent proposals for a European biogeographical regionalisation is the Biogeographic Map of Europe by RivasMartinez and Rivas-Saenz (2020). This includes fewer biogeographical regions, which are then divided into subregions, based primarily on endemics or spatially-delimited taxa and on a phytosociological legacy. Nonetheless, the EBRs map is the most commonly used and referenced scheme and the European Commission and the Council of Europe have adopted it for nature conservation purposes.

The current vector format version, published on the EEA website, contains 12 EBRs, including the 'outside data coverage' type (EEA 2019). Operational problems arise, however, when it is used in combination with the data used for reporting species and habitat information according to Article 17 of the Habitats Directive (Eionet Portal 2019a). These data are based on a grid of $7809 \times 10 \mathrm{~km} \times 10 \mathrm{~km}$ cells that covers the European territory (EEA 2017, Eionet Portal 2019b). Indeed, superimposing the vector format EBRs map on the European grid does not allow users to unambiguously associate a substantial number $(6881, \sim 5.87 \%)$ of the total of 117,177 individual $10 \mathrm{~km} \times 10 \mathrm{~km}$ grid cells to corresponding EBRs, since those cells overlap two or more biogeographical regions 
(Fig. 1). In addition, $928(\sim 0.84 \%)$ cells overlap one biogeographical region plus part of the 'outside' data area (Fig. 1).

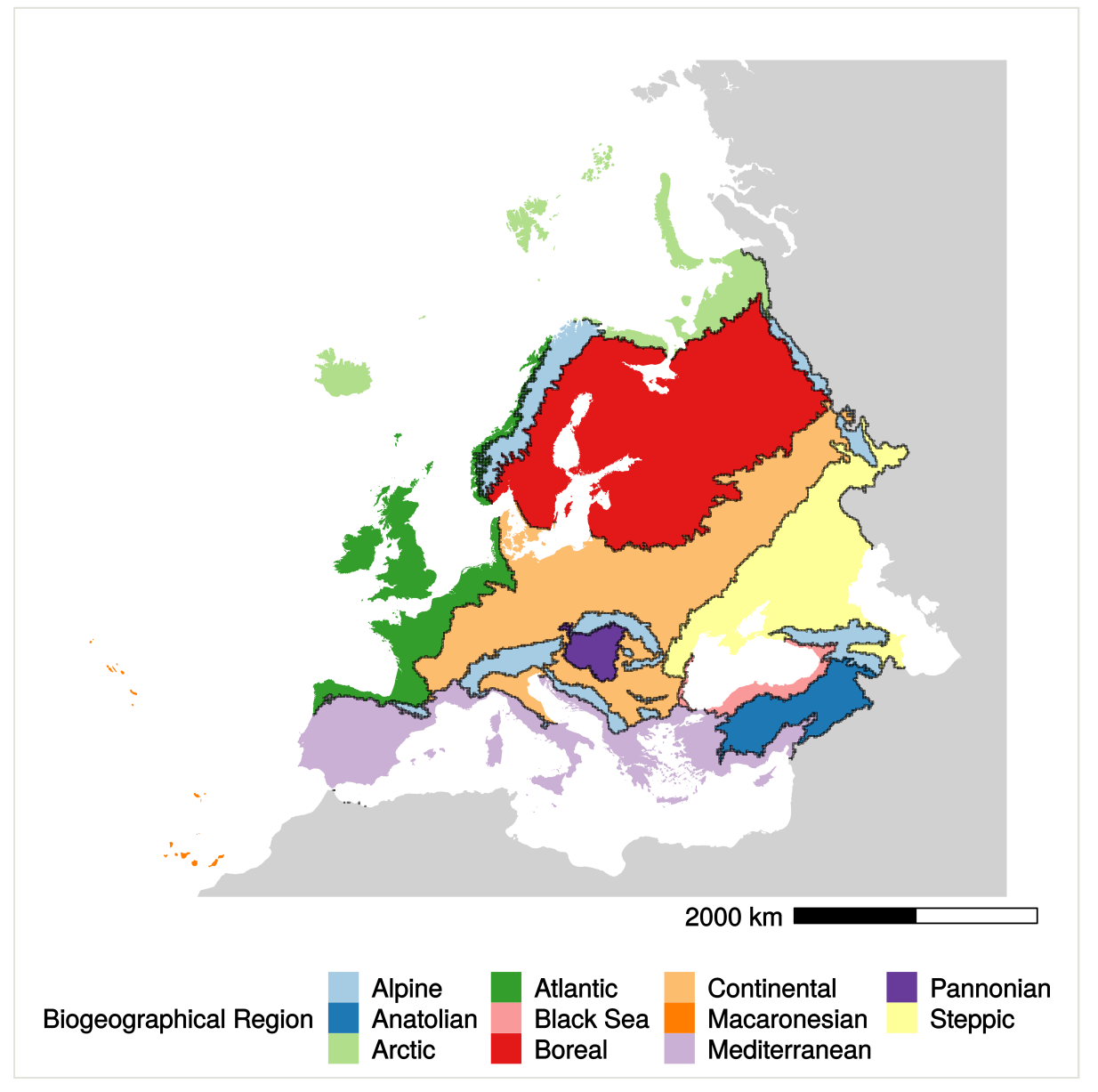

Figure 1. doi

Map of the 11 European Biogeographical Regions (EBRs) showing the $7809 \times 10 \mathrm{~km} \times 10 \mathrm{~km}$ cells containing two or more EBR boundaries. These cells are displayed as empty quadrats with black borders, but given the scale, appear as black lines unless zoomed in. (The 'outside data coverage' is here added in grey to show the geographical boundaries with the EBRs).

\section{General description}

Purpose: Here we present a new grid-based version of the European Biogeographical Regions map (GB-EBRs map). The dataset underpinning the GB-EBRs map is provided in Suppl. material 1. We have designed the GB-EBRs map to provide an operational tool for using the EBRs map along with grid-based data collected and used within the framework of 
the EU Habitats and Birds Directives. Our map aligns the EBR boundaries with the grid-cell boundaries, so that data associated with all the cells in the $10 \mathrm{~km} \times 10 \mathrm{~km}$ grid adopted for data reporting by Article 17 of the Habitats Directive can be unambiguously assigned to the 12 EBR classes (11 EBRs plus the 'outside data coverage' class). Our resulting map and the related dataset are available as an open-access resource for anyone wishing to use the EBRs map and data in the context of grid-based data.

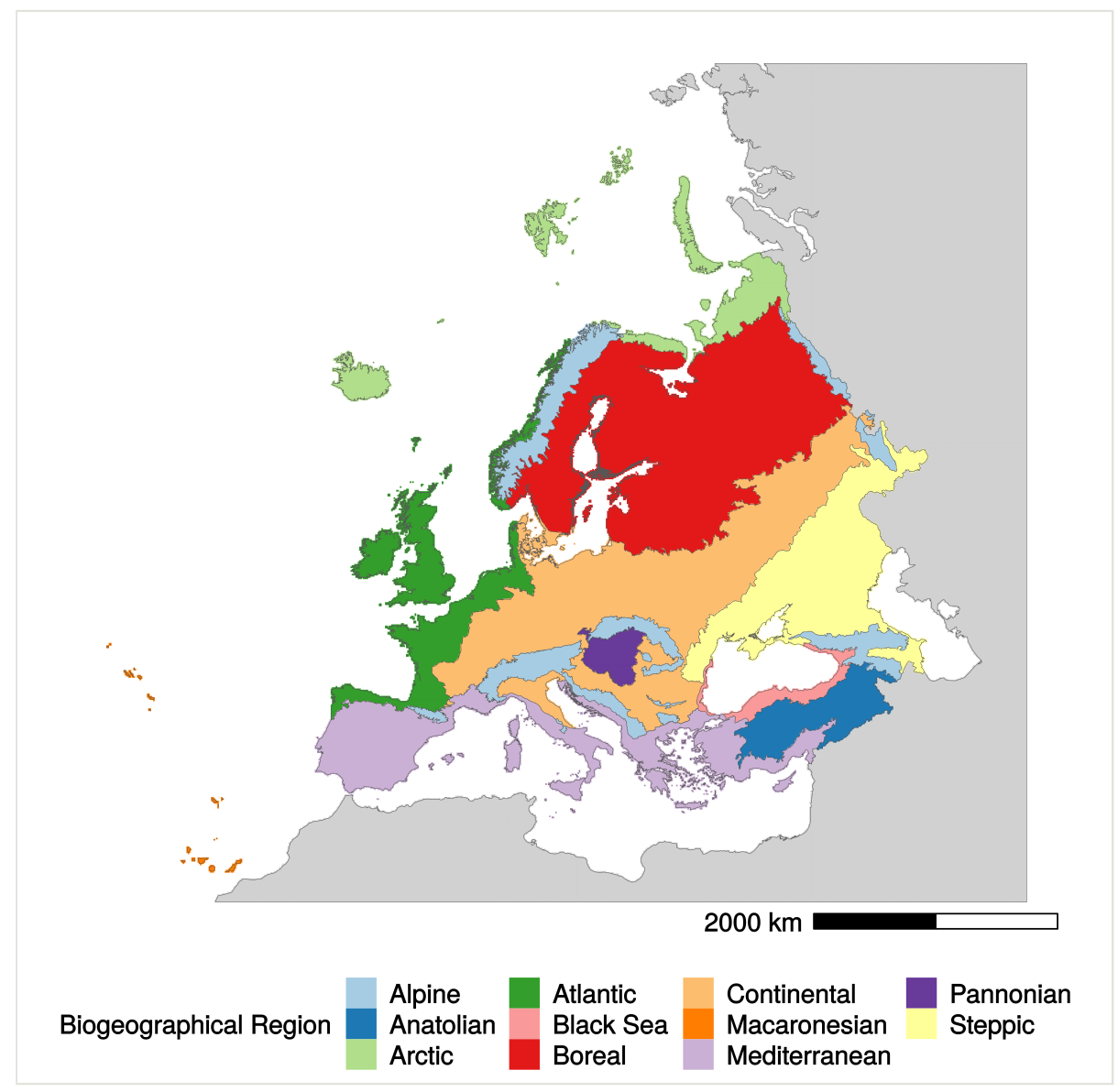

Figure 2. doi

Grid-Based Map of the 11 European Biogeographical Regions (plus the 'outside data coverage' in grey) at $10 \mathrm{~km} \times 10 \mathrm{~km}$ resolution (GB-EBR Map). This figure is provided only for the reader's convenience. The raster file is available at the URL: https://zenodo.org/record/ 3934962

Additional information: Our operational map represents a step towards standardising the regionalisation process of the EBRs, in compliance with the actions needed for monitoring the conservation status of habitats and species. These include the National Reports on the measures implemented and their effectiveness (Articles 11 and 17 of the Habitats Directive 
and Article 12 of the Birds Directive). Indeed, the monitoring of habitat types and species is strictly linked to the assessment of conservation status at the continental scale, i.e. the biogeographical regions (Ellwanger et al. 2018).

Applications of the GB-EBRs map go well beyond the data mandated by the Habitats and Birds Directives, since the same $10 \mathrm{~km} \times 10 \mathrm{~km}$ grid is widely used for both biotic and abiotic environmental variables. Many studies use these datasets for a broad range of purposes, including spatial investigations of species and habitat distributions (e.g. Hoffmann et al. 2018), improved climatologies for environmental and ecological studies (e.g. Karger et al. 2017), biodiversity conservation and prevention of habitat loss (Maiorano et al. 2015). In addition, the GB-EBRs map could be used to answer novel research questions, such as analysing beta diversity patterns amongst and within biogeographical regions (e.g. Chiarucci et al. 2019).

The GB-EBRs map is provided in Suppl. material 2 as a raster file at $10 \mathrm{~km}$ resolution containing distribution and boundaries of the 12 European Biogeographical Regions (EBRs - including the 'outside data coverage' EBR; see Fig. 2 for an outline). Details of the differences between the EBR boundaries reported in the official version of the EBRs map and the new ones reshaped on the new raster version (GB-EBRs) are shown in Fig. 3.

The GB-EBRs map is composed of $117,177 \times 10 \mathrm{~km} \times 10 \mathrm{~km}$ cells covering the $11 \mathrm{EBRs}$ (Table 1). The total area of the EBRs (sum of the surface in $\mathrm{km}^{2}$ for each $10 \mathrm{~km} \times 10 \mathrm{~km}$ cell belonging to each EBR) in this GB-EBRs map is a bit larger than in the official EBRs map since the inclusion of all the land surface in the GB-EBRs map resulted in some grid cells including some 'outside' areas, sea and oceans. This is particularly evident for the Macaronesian region, which is the smallest one and is composed only of islands; the area of this region is $10,255 \mathrm{~km}^{2}$ in the official EBRs map, but the cells assigned to it in our map total $24,700 \mathrm{~km}^{2}$. Nevertheless, the percentage of the surface area covered by 11 regions does not statistically differ between the original EBRs and the GB-EBRs map (Wilcoxon test for paired samples, $\mathrm{W}=61, \mathrm{P}=1.000)$.

\section{Sampling methods}

Sampling description: To develop the GB-EBRs map (Version 1.0), we adopted the following procedure that can be easily repeated (in case of changes in the EU territory or in the case of some eventual improvement or development of the EBRs). For each $10 \mathrm{~km} \times$ $10 \mathrm{~km}$ cell in the European grid, we calculated the percentage of area covered by each EBR. Then we assigned each cell to the EBR with the largest cover value therein. Assigning each cell to a region based only on area means that the assignment is not affected by the vagaries of cell centroids (e.g. the centroid happening to be in a class covering only a small proportion of the cell), as happens with common rasterisation algorithms. We also calculated the area of each EBR both in vector (i.e. official map) and raster (i.e. new map) format, in order to investigate the size differences. Data processing was performed with R 3.6.3 ( $\mathrm{R}$ Core Team 2019), using the packages exactextractr (Baston 2019), sf (Pebesma 2018) and raster (Hijmans 2019). Figures were made with 
ggplot2 package (Wickham 2016) with the support of RStoolbox (Leutner et al. 2019), rmapshaper (Teucher and Russell 2020), magrittr (Bache and Wickham 2014) and dplyr (Wickham et al. 2020) packages. We finally used the package Diplyr (Wickham et al. 2020) to realise the table with the dataset underpinning the GB-EBR map. The $R$ code used to produce the GB-EBR map and the related dataset is provided in Suppl. material 3
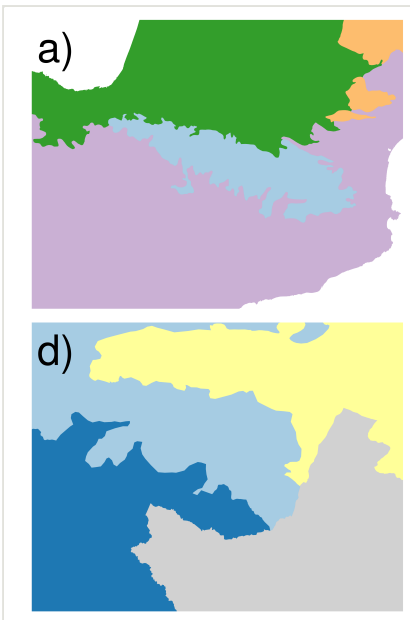
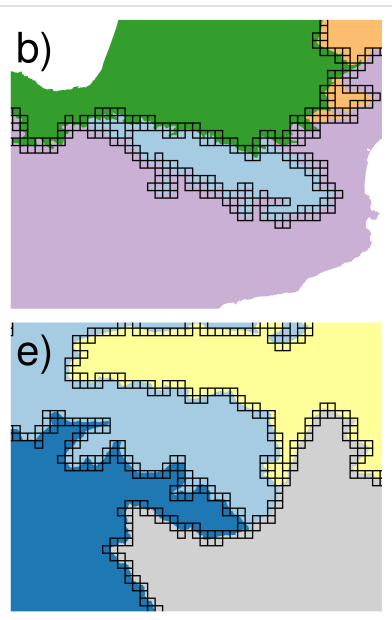
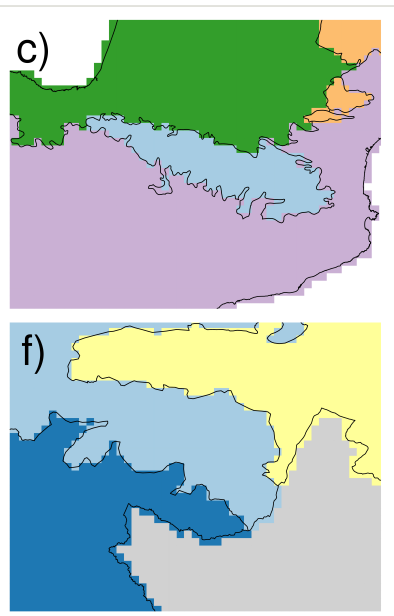

Figure 3. doi

Conversion of the EBR boundaries from the EBRs (vector) to the GB-EBRs (raster) map in two different geographical zones. Top row: Pyrenees - (a) Vector boundaries of Alpine, Atlantic, Continental and Mediterranean biogeographical regions, (b) $10 \mathrm{~km} \times 10 \mathrm{~km}$ cells that overlap two or more biogeographical regions, (c) comparison between the vector boundaries and the new grid-based ones in the GB-EBRs map. Bottom row: Caucasus - (d) Vector boundaries of Alpine, Anatolian, Steppic biogeographical regions plus 'outside data coverage', (e) $10 \mathrm{~km} \times 10 \mathrm{~km}$ cells that overlap two or more biogeographical regions, (f) comparison between the vector boundaries and the new grid-based ones, reshaped in the GB-EBRs map.

\section{Geographic coverage}

Description: Description: The map covers the European territory including the Azores, Madeira and the Canary Islands, but excludes seven outermost regions and the 13 overseas countries and territories.

\section{Usage rights}

Use license: Other

IP rights notes: The dataset is to be used in accordance with the terms and conditions of Attribution-NonCommercial 3.0 Unported (CC BY-NC 3.0) (https://creativecommons.org/ licenses/by-nc/3.0/) 
Table 1.

Comparison of the absolute and relative areas of each European Biogeographical Region according to the new proposed Grid-Based map (GB-EBRs Map) in comparison to the official vector map by the European Environmental Agency (EBRs Map).

\begin{tabular}{|c|c|c|c|c|c|}
\hline \multirow[b]{2}{*}{ Biogeographical Region } & \multirow{2}{*}{$\begin{array}{l}\text { GB-BGRs Map } \\
N^{\circ} \text { of cells }\end{array}$} & \multicolumn{4}{|l|}{ EBRs map } \\
\hline & & $\begin{array}{l}\text { Area } \\
\left(\mathrm{km}^{2}\right)\end{array}$ & $\begin{array}{l}\text { Area } \\
(\%)\end{array}$ & $\begin{array}{l}\text { Area } \\
\left(k^{2}\right)\end{array}$ & $\begin{array}{l}\text { Area } \\
(\%)\end{array}$ \\
\hline Alpine & 9731 & 973100 & 8.30 & 948235 & 8.60 \\
\hline Anatolian & 4468 & 446800 & 3.81 & 437310 & 3.97 \\
\hline Artic & 6877 & 687700 & 5.87 & 568701 & 5.16 \\
\hline Atlantic & 10127 & 1012700 & 8.64 & 861356 & 7.81 \\
\hline Black Sea & 1552 & 155200 & 1.32 & 139682 & 1.27 \\
\hline Boreal & 29337 & 2933700 & 25.04 & 2845317 & 25.81 \\
\hline Continental & 26021 & 2602100 & 22.21 & 2558880 & 23.21 \\
\hline Macaronesian & 247 & 24700 & 0.21 & 10255 & 0.09 \\
\hline Mediterranean & 13694 & 1369400 & 11.69 & 1192947 & 10.82 \\
\hline Pannonian & 1517 & 151700 & 1.29 & 151207 & 1.37 \\
\hline Steppic & 13606 & 1360600 & 11.61 & 1309196 & 11.88 \\
\hline Total & 117177 & 11717700 & 100 & 11023086 & 100 \\
\hline
\end{tabular}

\section{Data resources}

Data package title: Dataset of the grid-based map for the Biogeographical Regions of Europe (GB-EBR)

Resource link: https://zenodo.org/record/3934970

Alternative identifiers: https://doi.org/10.5281/zenodo.3766175

\section{Number of data sets: 1}

Data set name: Dataset underpinning the map entitled "A grid-based map for the Biogeographical Regions of Europe (GB-EBR)

Data format: Table

\begin{tabular}{|l|l|}
\hline Column label & Column description \\
\hline ID & Unique primary key \\
\hline
\end{tabular}




\begin{tabular}{|l|l|}
\hline CellCode & $10 \mathrm{~km} \times 10 \mathrm{~km}$ cell identification code with reference to longitude and latitude \\
\hline biogeographical_region & Biogeographical Region unambiguously associated to each $10 \mathrm{~km} \times 10 \mathrm{~km}$ cell \\
\hline $\mathrm{X}$ & Longitude of the $10 \mathrm{~km} \times 10 \mathrm{~km}$ cell centroid \\
\hline $\mathrm{Y}$ & Latitude of the $10 \mathrm{~km} \times 10 \mathrm{~km}$ cell centroid \\
\hline
\end{tabular}

\section{Author contributions}

$A C$ conceived the idea and supervised the project; $M C$ and $P Z$ developed the process for arriving to the GB-EBR map; DR conceived the approach and $\mathrm{PZ}$ developed the $R$ code to obtain the GB-EBR map. All the authors provided critical elements to the development of the GB-EBR map; MC drafted the first version of the manuscript. All the authors contributed to shape the final manuscript. Note: $M C$ and $P Z$ are equally contributing authors.

\section{References}

- 79/409/EEC (1979) The Birds Directive. https://ec.europa.eu/environment/nature/ legislation/birdsdirective/index en.htm. Accessed on: 2020-4-24.

- 92/43/EEC (1992) The Habitats Directive. https://ec.europa.eu/environment/nature/ legislation/habitatsdirective/index en.htm. Accessed on: 2020-4-24.

- $\quad$ Bache S, Wickham H (2014) magrittr: A forward-pipe operator for R. R package version 1.5. URL: https://CRAN.R-project.org/package=magrittr

- Bailey RG (2005) Identifying ecoregion boundaries. Environmental Management 34 (Suppl. 1): 14-26. https://doi.org/10.1007/s00267-003-0163-6

- $\quad$ Baston D (2019) exactextractr: Fast extraction from raster datasets using polygons. $R$ package version 0.1.1. URL: https://CRAN.R-project.org/package=exactextractr

- $\quad$ Bohn U (1993) Natural vegetation of Europe and Turkey. General Map 1:10.000.000. 1 (10).

- Bohn U, Gollub G, Hettwer C (2000) Karte der natrlichen Vegetation Europas. Massstab 1:2.500.000 Karten und Legende. Bundesamt fr Naturschutz

- Chiarucci A, Nascimbene J, Campetella G, Chelli S, Dainese M, Giorgini D, Landi S, Lelli C, Canullo R (2019) Exploring patterns of betadiversity to test the consistency of biogeographical boundaries: A case study across forest plant communities of Italy. Ecology and Evolution 9: 11716-11723. https://doi.org/10.1002/ece3.5669

- $\quad$ Chytrý M, Pyšek P, Wild J, Pino J, Maskell LC, Vilà M (2009) European map of alien plant invasions based on the quantitative assessment across habitats. Diversity and Distributions 15 (1): 98-107. https://doi.org/10.1111/j.1472-4642.2008.00515.x

- $\quad$ EEA (2017) EEA reference grid. https://www.eea.europa.eu/data-and-maps/data/eeareference-grids-2. Accessed on: 2020-4-24.

- $\quad$ EEA (2019) Biogeographical Regions. https://www.eea.europa.eu/data-and-maps/data/ biogeographical-regions-europe-3\#tab-metadata. Accessed on: 2020-4-24. 
- Eionet Portal (2019a) Reporting under Article 17 of the Habitats Directive. https:// www.eionet.europa.eu/etcs/etc-bd/activities/reporting/article-17. Accessed on: 2020-4-24.

- $\quad$ Eionet Portal (2019b) Eionet Central Data Repository. https://cdr.eionet.europa.eu. Accessed on: 2020-4-24.

- $\quad$ Ellwanger G, Runge S, Wagner M, Ackermann W, Neukirchen M, Frederking W, Mller C, Ssymank A, Sukopp U (2018) Current status of habitat monitoring in the European Union according to Article 17 of the Habitats Directive, with an emphasis on habitat structure and functions and on Germany. Nature Conservation 29: 57-78. https://doi.org/ 10.3897/natureconservation.29.27273

- $\quad$ ETC/BD (2006) The indicative map of European biogeographical regions: methodology and development. https://www.eea.europa.eu/data-and-maps/data/biogeographicalregions-europe-2005/methodology-description-pdf-format/methodology-description-pdfformat/download. Accessed on: 2020-4-24.

- Evans D (2005) Some uses of the map of the natural vegetation of Europe for Natura 2000. Conference paper. Conference: Application and Analysis of the Map of the Natural Vegetation of Europe 2005, 195-204 Bundesamt für Naturschutz.

- $\quad$ Evans D (2012) Building the European Unions Natura 2000 network. Nature Conservation 1: 11-26. https://doi.org/10.3897/natureconservation.1.1808

- Fattorini S (2016) A history of chorological categories. History and Philosophy of the Life Sciences 38 (12). https://doi.org/10.1007/s40656-016-0114-1

- Fattorini S (2017) Endemism in historical biogeography and conservation biology: concepts and implications. Biogeographia - The Journal of Integrative Biogeography 32: 47-75. https://doi.org/10.21426/B632136433

- Ferro I, Morrone JJ (2014) Biogeographical transition zones: a search for conceptual synthesis. Biological Journal of the Linnean Society 113 (1): 1-12. https://doi.org/ $10.1111 / \mathrm{bij} .12333$

- Ficetola GF, Mazel F, Thuiller W (2017) Global determinants of zoogeographical boundaries. Nature Ecology \& Evolution 1: 89. https://doi.org/10.1038/s41559-017-0089

- Freitag H (1962) Einführung in die Biogeographie von Mitteleuropa - unter besonderer Berücksichtigung von Deutschland. Fischer, Stuttgar, 216 pp.

- Hijmans RJ (2019) raster: Geographic data analysis and modeling. R package version 3.0-7. URL: https://CRAN.R-project.org/package=raster

- Hoffmann S, Beierkuhnlein C, Field R, Provenzale A, Chiarucci A (2018) Uniqueness of protected areas for conservation strategies in the European Union. Scientific Reports 8 (6445). https://doi.org/10.1038/s41598-018-24390-3

- Hoffmann S, Irl S DH, Beierkuhnlein C (2019) Predicted climate shifts within terrestrial protected areas worldwide. Nature Communications 10 (4787). https://doi.org/10.1038/ s41467-019-12603-w

- Holt BG, Lessard JP, Borregaard MK, Fritz SA, Araújo MB, Dimitrov D, Fabre PH, Graham CH, Graves GR, Jønsson KA, Nogués-Bravo D, Wang Z, Whittaker RJ, Fjeldså J, Rahbek C (2013a) An update of Wallaces zoogeographic regions of the World. Science 339 (6115): 74-78. https://doi.org/10.1126/science.1228282

- Holt BG, Lessard JP, Borregaard MK, Fritz SA, Araújo MB, Dimitrov D, Fabre PH, Graham CH, Graves GR, Jønsson KA, Nogués-Bravo D, Wang Z, Whittaker RJ, Fjeldså J, Rahbek C (2013b) Response to comment on an update of Wallaces zoogeographic 
regions of the World. Science 341 (6144): 74-78. https://doi.org/10.1126/science. 1237541

- Ibáñez JJ, Zinck JA, Dazzi C (2013) Soil geography and diversity of the European biogeographical regions. Geoderma 192: 142-153. https://doi.org/10.1016/j.geoderma. 2012.07.024

- Illies J (1967) Limnofauna Europaea. Eine Zusammenstellung aller die europäischen Binnengewässer bewohnenden mehrzelligen Tierarten $\mathrm{m}$. Angaben über $\mathrm{d}$. Verbreitung u. Ökologie. 1st Edition. Fischer, Stuttgart, 474 pp.

- Illies J (1978) Limnofauna Europaea. A checklist of the animals inhabiting European inland waters, with an account of their distribution and ecology. 2nd Edition. Fischer Verlag, Stuttgart, $552 \mathrm{pp}$.

- $\quad$ Karger DN, Conrad O, Bhner J, Kawohl T, Kreft H, R.W S, Zimmermann NE, Linder HP, Kessler M (2017) Climatologies at high resolution for the earths land surface areas. Scientific Data 4 (170122). https://doi.org/10.1038/sdata.2017.122

- Kreft H, Jetz W (2010) A framework for delineating biogeographical regions based on species distributions. Journal of Biogeography 37 (11): 2029-2053. https://doi.org/ 10.1111/jbi.2010.37

- $\quad$ Kreft H, Jetz W (2013) Comment on An update of Wallaces zoogeographic regions of the world. Science 341 (6144): 343. https://doi.org/10.1126/science.1237471

- $\quad$ Leutner B, Horning N, Schwalb-Willmann J (2019) RStoolbox: Tools for remote sensing data analysis. R package version 0.2.6. URL: https://CRAN.R-project.org/ package $=$ RStoolbox

- $\quad$ Lomolino MV, Riddle BR, Whittaker RJ, Brown JH (2005) Biogeography. 4th. Sinauer Associates, 375 pp. https://doi.org/10.1111/j.1365-2699.2005.01314.x

- Maiorano L, Amori G, Montemaggiori A, Rondinini C, Santini L, Saura S, Boitani L (2015) On how biodiversity is covered in Europe by national protected areas and by the Natura 2000 network: insights from terrestrial vertebrates. Conservation Biology 29 (4): 986-995. https://doi.org/10.1111/cobi.12535

- Morrone JJ (2015) Biogeographical regionalization of the world: a reappraisal. Australian Systematic Botany 28 (3): 81-81. https://doi.org/10.1071/SB14042

- Morrone JJ (2018) The spectre of biogeographical regionalization. Journal of Biogeography 45 (2): 282-288. https://doi.org/10.1111/jbi.13135

- Mucina L (2019) Biome: evolution of a crucial ecological and biogeographical concept. New Phytologist 222 (1): 97-114. https://doi.org/10.1111/nph.15609

- Noirfalse A (1987) Carte de la végétation naturelle des Etats membres des Communautés européennes et du Conseil de l'Europe. 1: 3.000.000, deuxième édition. Luxembourg. (Office public. off. Comm. europ.), feuilles 1-4.

- Ordynets A, Heilmann-Clausen J, Savchenko A, Bässler C, Volobuev S, Akulov O, Karadelev M, Kotiranta H, Saitta A, Langer E, Abrego N (2018) Do plant-based biogeographical regions shape aphyllophoroid fungal communities in Europe? Journal of Biogeography 45 (5): 1182-1195. https://doi.org/10.1111/jbi.13203

- Pebesma E (2018) Simple features for R: Standardized support for spatial vector data. The R Journal 10 (1): 439-446. https://doi.org/10.32614/RJ-2018-009

- $\quad$ R Core Team (2019) R: A language and environment for statistical computing. $R$ Foundation for Statistical Computing, Vienna, Austria. https://www.R-project.org/. Accessed on: 2020-4-24. 
- Rivas-Martinez S, Rivas-Saenz S (2020) Worldwide Bioclimatic Classification System, Phytosociological Research Center, Spain. http://www.globalbioclimatics.org. Accessed on: 2020-6-08.

- Roekaerts M (2002) The Biogeographical Regions Map of Europe. Basic principles of its creation and overview of its development. European Topic Centre Nature Protection and Biodiversity (EEA). https://www.eea.europa.eu/data-and-maps/data/ biogeographical-regions-europe-2001/methodology-basic-principles-of-thebiogeographical-regions-map-creation-and-overview-of-its-development/methodologybasic-principles-of-the-biogeographical-regions-map-creation-and-overview-of-itsdevelopment/at download/file. Accessed on: 2020-6-08.

- Rueda M, Rodríguez MÁ, Hawkins BA (2010) Towards a biogeographic regionalization of the European biota. Journal of Biogeography 37 (11): 2067-2076. https://doi.org/ 10.1111/j.1365-2699.2010.02388.x

- Templ B, Templ M, Filzmoser P, Lehoczky A, Bakšienè E, Fleck S, Gregow H, Hodzic S, Kalvane G, Kubin E, Palm V, Romanovskaja D, Vučetić V, žust A, Czúcz B, NS-Pheno Team (2017) Phenological patterns of flowering across biogeographical regions of Europe. International Journal of Biometeorology 61: 1347-1358. https://doi.org/10.1007/ s00484-017-1312-6

- Teucher A, Russell K (2020) rmapshaper: Client for 'mapshaper' for 'Geospatial' Operations. R package version 0.4.3. URL: https://CRAN.R-project.org/ package=rmapshaper

- Walter H (1954) Arealkunde. Einführung in die Phytologie III/2. Ulmer, Stuttgart, 245 pp.

- Walter H, Breckle SW (2002) Walters vegetation of the Earth - The ecological systems of the geo-biosphere. Springer, $572 \mathrm{pp}$.

- Wickham H (2016) ggplot2: Elegant graphics for data analysis. Springer-Verlag. (VIII), 213 pp. https://doi.org/10.1007/978-3-319-24277-4

- Wickham H, François R, Henry L, Müller K (2020) dplyr: A Grammar of Data Manipulation. R package version 0.8.5. URL: https://CRAN.R-project.org/package=dplyr

\section{Supplementary materials}

\section{Suppl. material 1: Dataset of the grid-based map for the Biogeographical Regions of Europe (GB-EBR) - (Version 0.1.0) doi}

Authors: Cervellini M, Zannini P, Di Musciano M, Fattorini S, Jiménez-Alfaro B, Rocchini D, Field R, Vetaas OR, Irl SDH, Beierkuhnlein C, Hoffmann S, Fischer JC, Casella L, Angelini P, Genovesi $\mathrm{P}$, Nascimbene J, Chiarucci A

Data type: dataset

Brief description: Here we provide the dataset underpinning the map entitled "A grid-based map for the Biogeographical Regions of Europe (GB-EBR)"

https://zenodo.org/record/3934970

Download file (10.80 MB) 


\section{Suppl. material 2: A grid-based map for the Biogeographical Regions of Europe} (GB-EBR) doi

Authors: Cervellini M, Zannini P, Di Musciano M, Fattorini S, Jiménez-Alfaro B, Rocchini D, Field R, Vetaas OR, Irl SDH, Beierkuhnlein C, Hoffmann S, Fischer JC, Casella L, Angelini P, Genovesi $P$, Nascimbene J, Chiarucci A

Data type: raster

Brief description: Here we provide the grid-based map of the European Biogeographical Regions of Europe (GB-EBR). The borders of the EBRs are reshaped to coherently match the standard European $10 \mathrm{~km} \times 10 \mathrm{~km}$ grid, thus allowing each EBR to be unambiguously assigned to a single $10 \mathrm{~km} \times 10 \mathrm{~km}$ cell.

https://zenodo.org/record/3934968

Download file $(172.69 \mathrm{~kb})$

Suppl. material 3: The R code developed to produce the GB-EBR map doi

Authors: Zannini P

Data type: script; text

Download file $(2.46 \mathrm{~kb})$ 